\title{
MEDIALNY, ŚWIĘTY. JAN PAWEŁ II W POEZJI WSPÓŁCZESNEJ
}

Jan Paweł II to nie tylko pisarz, ale także niezwykle popularny bohater współczesnych utworów literackich. Jego postać jest wspólnym dobrem polskiej poezji, która wytrwale towarzyszyła pontyfikatowi rodaka od momentu jego wyboru na Stolicę Piotrową aż po obrzędy pogrzebowe. Wśród literackich wizerunków Jana Pawła II znajduje się m.in. portret Papieża medialnego. Wiemy, że Ojciec Święty świetnie wpisywał się w potrzeby i możliwości współczesnej telewizji (por. Wołpiuk; Gabiś1) i ,stał się największym teleewangelistą świata” (Ikonowicz 12). Jak się okazuje, ów fenomen zauważali także poeci. Dwóm wierszom chciałbym przyjrzeć się w sposób szczególny.

Tekst Tadeusza Dąbrowskiego powstał w 2002 roku i wtedy też doczekał się publikacji na łamach Lampy i Iskry Bożej (2002, nr 20 (25)) ${ }^{2}$. Wkrótce ów drobny liryk zaczął jednak żyć osobnym życiem, przedostając się do przestrzeni komunikacji masowej jako poetycki reportaż, który reaguje na bieżące, nagłośnione wydarzenia.

Prof. dr hab. WojcIEch KudyBA - kierownik Katedry Polskiej Literatury Współczesnej i Krytyki Literackiej w Instytucie Literaturoznawstwa UKSW; adres do korespondencji: Uniwersytet Kardynała Stefana Wyszyńskiego, ul. Dewajtis 5,01-815 Warszawa; e-mail: w.kudyba@uksw.edu.pl. ORCID: http://orcid.org/0000-0001-5868-3850.

${ }^{1}$ Tekst ukazał się najpierw w periodyku Acana, korzystam jednak z jego rozszerzonej wersji, dostępnej w Internecie.

${ }^{2}$ Niech mi wolno będzie w tym miejscu podziękować Tadeuszowi Dąbrowskiemu za tę i kilka innych informacji o utworze. 
Pojawił się zatem zarówno na łamach popularnych czasopism ${ }^{1}$, jak i na forach internetowych ${ }^{2}$. Stopniowo otoczyły go liczne komentarze, których cechą wspólną jest styl odbioru skierowany na uchwycenie relacji łączącej przekaz poetycki z przekazami medialnymi (Babuchowski, Sinkowski). Trudno się temu dziwić. Od 2003 roku oczy kamer stosunkowo często przyciągało wydarzenie starości i choroby Papieża, który - inaczej niż jego poprzednicy - świadomie pozwalał uczestniczyć widzom telewizyjnym w swoim powolnym odchodzeniu. Jak pamiętamy, intensywność tego osobliwego przekazu wzmogła się w roku 2004 i narastała z miesiąca na miesiąc. Jak pisze Tomasz Gabiś, właśnie wtedy „miliony ludzi na całym świecie mogły w domowym zaciszu albo przed telebimami przeżywać ostatnią drogę papieża, każdy grymas bólu, każde poruszenie drżącej ręki” (Gabiś). Obszernej analizy tego rozgrywającego się na oczach całego świata dramatu dokonuje m.in. Marco Politi, przypominając sobie i nam, jak obiektywy telewizyjnych kamer chwytały wówczas ,poruszenia warg, strzępy słów, nitki śliny cieknącej z ust” (Politi 43) - narastające zmęczenie i fizyczną bezsilność Ojca Świętego. Wiersz Tadeusza Dąbrowskiego ma u swych źródeł tamto zbiorowe doświadczenie zapośredniczonego w mediach uczestnictwa w bólu Papieża. Przywołajmy ów liryk w całości:

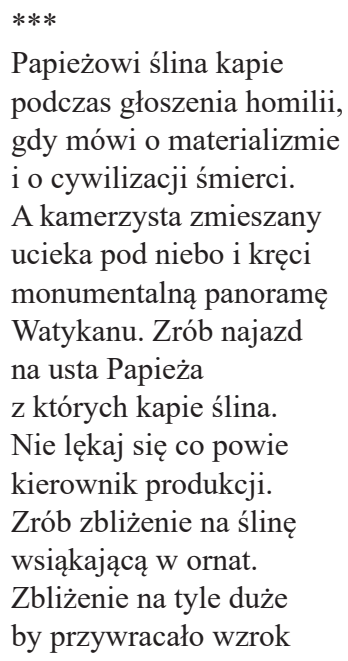

(Dąbrowski 30)

Opis, jaki pojawia się w pierwszych czterech wersach utworu, może sugerować, że mamy do czynienia z relacją świadka i uczestnika papieskiej homilii, wygłaszanej

\footnotetext{
${ }^{1}$ Por. m.in. Studium, nr 2-3, 2004, s. 30.

${ }^{2}$ Długa dyskusja wokół tekstu toczyła się zwłaszcza na forum „Nieszuflada”, nieszuflada.pl/klasa. asp?idklasy $=112198 \&$ idautora $=10188 \&$ rodzaj $=5$.
} 
podczas liturgii lub podczas którejś z środowych audiencji generalnych. Kolejne cztery wersy każą jednak zweryfikować podobne przypuszczenia. Okazuje się, że to, co widzi i opisuje osoba mówiąca w wierszu, jest nie tyle samą rzeczywistością, ile raczej jej telewizyjnym obrazem. Wskazuje na to nie tylko motyw operatora kamery, ale także, a nawet przede wszystkim charakterystyczny dla wypowiadającego się podmiotu sposób percepcji bodźców wzrokowych i dźwiękowych. Trudno tu przecież mówić o medytacyjnym wpatrywaniu się czy nawet o uważnej obserwacji. Wspomniane, inicjalne wersy są zapisem spostrzeżenia - rozpoznania, którego istotą jest momentalność i migawkowość. Jego korelatem nie jest świat otwarty na wszelkie formy niespiesznego poznawania, lecz kadr telewizyjnej kamery, z samej swej natury chwilowy. To, co zostało dostrzeżone, można opisać językiem filmu jako pojedyncze ujęcie - prezentujące symptomy choroby Papieża na dźwiękowym tle słów jego katechezy. Powtórzmy: świadek i uczestnik, który wypowiada się w utworze, jest świadkiem i uczestnikiem telewizyjnej transmisji.

Czy Tadeusz Dąbrowski świadomie nadaje zatem podmiotowi wiersza rysy everymana - przeciętnego użytkownika współczesnych mediów? Zapewne tak. Jak zauważyli krytycy, współczesny „człowiek masowy” jest ulubionym bohaterem gdańskiego pisarza, mocno wpisując się w poetykę jego utworów ${ }^{1}$. Tym bardziej więc wypada podkreślić fakt, że $\mathrm{w}$ analizowanym liryku autor wyposaża protagonistę w cechy, które nie zawsze da się przypisać statystycznemu konsumentowi przekazów telewizyjnych. Trudno nie zauważyć, że ten, kto opisuje całą scenę, od początku wie, że kontaktuje się nie tyle z rzeczywistością samą w sobie, ile raczej z jej medialnym obrazem, tworzonym wedle ściśle określonych zasad ${ }^{2}$. Owocem tej wiedzy staje się krytyczny dystans wobec sposobu realizacji transmisji - pozwalający na dokonanie błyskawicznej analizy i oceny zabiegów operatora, przystosowującego pracę kamery do reguł telewizyjnego przekazu. To właśnie coś, co należałoby nazwać świadomością medialną, pozwala podmiotowi wiersza zobaczyć to, czego zazwyczaj nie zauważa przeciętny odbiorca masowych mediów. Właśnie świadomość medialna pozwala mu dostrzec zmianę ujęcia w charakterystycznym momencie transmisji i umożliwia rozpoznanie motywów, skłaniających operatora do takiego właśnie działania.

Warto na chwilę pochylić się nad nimi i przyjrzeć się im dokładniej. Jak czytamy, „kamerzysta zmieszany/ ucieka pod niebo i kręci /monumentalną panoramę

${ }^{1}$ Pisze o tym wielu krytyków. Por. np. Rabizo-Birek 89; Śliwiński 48; Kudyba, „Lekkość, uwieranie" 134).

${ }^{2}$ „Uczestniczący we Mszy mają przed oczami co innego niż ci oglądający ją w telewizji, ponieważ ci drudzy widzą mszę «reżyserowaną», w różnych ujęciach, ze zbliżeniami itd." - zauważa trzeźwo Gabiś (Gabiś). 
/ Watykanu". Podmiot mówiący daje do zrozumienia, że bezpośrednim powodem zmiany ujęcia jest konsternacja operatora. Co jednak wiemy o jej źródłach? Kontekst cytowanych wersów pozwala postawić kilka interesujących i niewykluczających się wzajemnie hipotez. Zdanie ,nie lękaj się, co powie kierownik produkcji” trudno przecież uznać za wystarczające wyjaśnienie sytuacji. Lęk przed opinią przełożonego rzadko bywa zupełnie irracjonalny. Zwykle wyrasta z poczucia winy, ze świadomości niedopełnienia jakiegoś obowiązku lub naruszenia jakichś zasad. Jakie więc reguły telewizyjnej transmisji nakazywały ominięcie kamerą twarzy papieża właśnie wtedy, gdy z kącika jego ust spłynęła ślina? Arkadiusz Morawiec pisze w swym interesującym tekście o naruszonym tabu estetycznym, o tym, że sopocki poeta „pozostaje krytyczny wobec wynikającego z reguły stosowności «przeoczania» tego, co «nieestetyczne», a z tym, tego, co istotne" (Morawiec 89). Trudno odmówić tym twierdzeniom słuszności - to oczywiste, że każdy operator kamery porusza się w ramach estetyki komunikatów wizualnych. Równie trudno jednak powstrzymać wyobraźnię interpretacyjną, która - w żaden sposób nie podważając cytowanych wyżej konstatacji - pozwala uzupełnić je o dodatkowe elementy. Najpierw chciałoby się bowiem przypomnieć, że podmiot wiersza świetnie zdaje sobie sprawę, że analizuje przekaz audiowizualny. Wcale nie ogranicza się do analizy obrazu, lecz odnosi się również do warstwy dźwiękowej. Wyraźnie mówi nam o tym, że operator przestaje ukazywać twarz Ojca Świętego w momencie, gdy padają słowa „o materializmie / i o cywilizacji śmierci". Sugeruje więc tym samym, że tabu estetyczne nie jest być może jedynym, jakie funkcjonuje w świecie mediów. To, w stronę którego kieruje nasze intuicje, trzeba nazwać chyba tabu ideologicznym, bo dotyczy ono sfery idei i wartości. Potencjalny widz ma odwrócić swój wzrok od Papieża właśnie wtedy, gdy ten krytycznie odnosi się do dominujących tendencji współczesnej kultury Zachodu. Ruch kamery operatora - powiada wiersz - pozostaje zgodny z charakterystycznym dla wielu współczesnych ośrodków opiniotwórczych gestem odrzucenia lub lekceważenia profetycznych wymiarów posługi Jana Pawła $\mathrm{II}^{3}$. Krytyka zachodniego stylu życia - nawet jeśli płynie z ust Ojca Świętego - ulega w przekazie medialnym znaczącemu osłabieniu. Czy dlatego, że materializm (lub konsumpcjonizm) stanowi sam rdzeń istnienia mass mediów? - zdaje się pytać autor wiersza ${ }^{4}$. Dlaczego jednak - mając tak wiele innych możliwości - zamiast zmęczonej twarzy schorowanego Papieża operator ukazuje „monumentalną panoramę Watykanu”. Jakie symboliczne

${ }^{3} \mathrm{O}$ dokonanej we współczesnej popkulturze tabuizacji profetycznej posługi Ojca Świętego czytamy m.in. w artykule Krzysztofa Mazura (18-27).

${ }^{4} \mathrm{~K}$. Wołpiuk w cytowanym artykule wspomina m.in.: „W czasie, gdy wielu ludzi oskarżyłoby telewizję jako teren sprzyjający materializmowi i, poprzez reklamę, zwiastun szalejącego konsumizmu, Jan Paweł II widzi w niej ogromny potencjał przekazu duchowego" (176). 
sensy poeta wpisał w gest przeniesienia oka kamery z pozbawionej patosu twarzy starego człowieka na monumentalne oblicze państwa? Czy nie zaprasza nas do odkrycia jeszcze jednego tabu, które chciałoby się nazwać - instytucjonalnym? To o nim czytamy w cytowanym artykule Tadeusz Gabisia:

[...] choroby i umieranie króla były w miarę możliwości przemilczane i nie wystawiane na widok publiczny. [...] Świadome wystawienie na widok publiczny kruchości ciała naturalnego [...] było maksymalnym zhumanizowaniem i zindywidualizowaniem Króla, mającym naocznie zademonstrować, że ma on tylko jedno naturalne ciało. Ciało polityczne (instytucjonalne) rozpłynęło się, pozostało ciało fizyczne - chore, cierpiące i umierające arcyludzkie ,ja”. (Gabiś)

W świetle przywołanej wypowiedzi publicysty, gest zastąpienia obrazu Jana Pawła II obrazem Watykanu można więc interpretować jako próbę dowartościowania władzy przywódcy watykańskiego państwa, której majestatu w żaden sposób niepodobna było pokazać w twarzy cierpiącego starca. Analizowany wers skłania w każdym razie do namysłu nad skłonnością współczesnych mediów do kreowania idoli i do unikania tego wszystkiego, co mogłoby obniżyć atrakcyjność ich wizerunku. Ta bowiem - jak piszą znawcy - „to warunek sine qua non idola, jego pierwszorzędna i konstytutywna cecha" (Skórczewski 101). Obraz Ojca Świętego, jaki ma się przedostać do świadomości odbiorcy, ma być wizualizacją potęgi i wzniosłości - być może zachowanie operatora wynika z interioryzacji takiej właśnie zasady.

Wszystko to nie zmienia przecież faktu, że tym, co uderza w wierszu Dąbrowskiego, jest nie tyle subtelność medioznawczych intuicji, ile raczej radykalizm i skala protestu, sformułowanego przez liryczny podmiot. Nietrudno dostrzec, że dyskurs opisowy wypełnia jedynie pierwszą połowę utworu. Że ósmy wers rozpada się na dwie części. Pierwsza jest końcówką deskrypcji, druga - otwiera serię bezpośrednich zwrotów do adresata, która trwa do końca wiersza i nadaje mu charakter liryki apelu. Osią konstrukcyjną zakończenia liryku stają się trzy rozkaźniki: „Zrób najazd na usta papieża [...] nie lękaj się co powie / kierownik produkcji. / Zrób zbliżenie na ślinę". Jeśli nadal mamy przed oczami ewokowany w pierwszej części utworu obraz przeciętnego odbiorcy telewizyjnej transmisji i jej ukrytego producenta, to właśnie uległ on destrukcji. Jego istotą jest przecież wyraźne rozdzielenie ról pasywnych i aktywnych. Telewizyjnym widzom przypisuje się te pierwsze, zaś producentom, operatorom kamer i „aktorom” - drugie. W wierszu Dąbrowskiego ów porządek (znany z kart podręczników medioznawstwa, por. Kosmanowa) zostaje poważnie naruszony, a następnie - obalony. Podmiot poety zrywa z konwencjami tzw. starych mediów i zachowuje się tak, jak przystało na użytkownika mediów interaktywnych: nie chce pozostać biernym przedmiotem medialnych działań, jest świadomy swej podmiotowości i możliwości wpływu na jakość oraz treść transmisji. Właśnie dlatego domaga się od operatora kamery ściśle określonych czynności. 
Układ podmiotowo-przedmiotowy - którego jedną częścią jest wszechmogący nadawca, a drugą bierny i nieświadomy odbiorca - zostaje więc zastąpiony relacją partnerską, opartą na zasadach dialogu. Upodmiotowiony odbiorca korzysta w wierszu z prawa zabrania głosu w dyskusji nad sposobem realizacji transmisji. Choć jego wypowiedzi mają charakter performatywny i przede wszystkim zachęcają do działania, to jednak nie są zupełnie pozbawione argumentacji. Zmiana ujęcia, do której nawołuje, wydaje się związana z przewartościowaniem zasad regulujących pracę kamery. Zdaniem tego, kto wypowiada się w wierszu, istnieją normy ważniejsze niż te, które nakazywały operatorowi zdjąć oko obiektywu z twarzy Jana Pawła II. Zapytajmy więc o nie - o takie zasady przekazu, które unieważniają regułę atrakcyjności, estetyki oraz patosu wizerunku telewizyjnego bohatera. Zadanie nie jest łatwe, bo poeta nie mówi o nich wprost. Dowiadujemy się nie tyle o przyczynach apelu skierowanego do kamerzysty, ile raczej o performatywnych skutkach ewentualnej zmiany obrazu. Zdaniem podmiotu, wykonane przez operatora zbliżenie może w istotny sposób oddziaływać na odbiorcę i zmieniać jego zdolności percepcyjne. Charakter i sens owej zmiany skrywa w sobie efektowna metafora przywracania wzroku. Odbiorca - patrząc na ślinę wsiąkającą w ornat - ma szansę odzyskać wzrok. Będzie w stanie zobaczyć coś, czego do tej pory nie zauważał. Co właściwie? Czy prawdę o kimś, kto, jak się okazuje, nie jest wykreowanym przez media idolem, lecz cierpiącym starcem? A może to, że nasza relacja z nim nie musi być bezosobowa - nie musi być powierzchownym podziwem dla majestatu, lecz może przerodzić się w głębokie, osobiste współczucie, jakiego domaga się każdy cierpiący człowiek? A może chodzi poecie o to, że orędzie Jana Pawła II kierowane do współczesności, jego uparta krytyka ślepych zaułków naszej cywilizacji uzyskuje szczególną wiarygodność i egzystencjalny ciężar właśnie dzięki temu, że pada z ust wykrzywionych chorobą i bólem zniedołężniałego organizmu? Puenta wiersza jest synekdochą. Przenosi naszą uwagę z pojedynczego telewizyjnego kadru w obszar refleksji nad rolą mediów w naszym cyfrowym świecie. Poeta zdaje się sugerować, że może należeć do niej pobudzanie wrażliwości na prawdę o człowieku oraz stymulowanie naszego uwrażliwienia na godność i wartość każdej osoby - zwłaszcza najsłabszej. Podmiot utworu jest moralistą. Jego spostrzeżenia i apele mieszczą się w obszarze etyki mediów.

Horyzont znaczeniowy wiersza Tadeusza Dąbrowskiego obejmuje zatem te wymiary religijności, które można wiązać z moralnością. Autor świadomie wybiera spośród bogatego spektrum fenomenu religii - mieszczącego w sobie m.in. również 
doktrynę, liturgię i duchowość - jeden aspekt, chciałoby się powiedzieć: jeden kadr i na nim koncentruje swoją uwagę. Podobnie dzieje się w dyptyku Romana Bąka Biały niedźwiedź, tyle że poznański poeta kieruje swą uwagę przede wszystkim na osobiste odniesienia osoby do nadprzyrodzoności. Dlatego też chciałbym potraktować ów minipoemat jako ważne dopełnienie etycznej troski gdańskiego poety.

biały niedźwiedź

Ojcu Świętemu

1. głosy

piękny jest nasz miś nasz biaty miś piękny i taki grzeczny i ładny za trzy talary pokazuje sztuke otrząsa gęstą sierść aż z niej lukiem spada śnieg puch zbity w kulke

za sześć unosi jedna z łap i trzyma tak nisko nad ziemia druga wsparty o niebo jakby byt zapomnianym pomnikiem a jeśli dorzucić jeszcze dwa chwyta za miecz

za dziesięć talarów miś gra bębni na wielkim bębnie pięknie aż skóra napięta do granic nie rozleci się nie pęknie $w$ szwach biega miś bębni miś za nic nie chce przestać grać

ale niech tylko krzykna mu: tańcz to miś tańczyć zaczyna po śmietniskach szynach szktach $z$ nogi na noge przestępuje w takt marsza potyka sięfatszuje

a potem unosi się i lata latawiec na smyczy wiatr miota nim szarpie ryczy ale nikt nie wierzy mu każdy wie $\dot{z}$ e to sztuczka że to na sznurkach $i \dot{z} e$ żaden miś latać nie umie 
2. ballada

zrywa się biaty niedźwiedź szarpie rzemień przegryza pętle

w cień nocy uchodzi na zew

idzie sam ścieżka której nikt nie zna styszy gtos którego nikt nie styszy

ścieżka jest kamienna

zmęczony dniem człapie ciężko

boli go kark bola go tapy $i$ krzyż

sapie wlecze ogromne cielsko

wokót dzicz sktębiony ogród

gór trzask skaliste echo

iść nie przestać iść chtód i ciemność

staje wreszcie na skale $w$ dole

lśni po nocy błękitny zdrój

biaty niedźwiedź schodzi nad wode

w jasnej toni kotysze się bije

dzwon spiżowy pótnocna godzine

jeszcze głębiej nikłe światetko

wodo żywa krynico blasku

krypto ciszy płomieniu taski

ukojenie pragnacych przystań

schyla kark niedźwiedź schyla i pije

głos podzwonny zaklęty w krople

każda z nich perta przeczysta

[...]

śpiewa ból swój kamień cierpienia

zbrodnie śpiewa klamliwych dni

umęczona żali się ziemia

śpiewa głód śpiewa nędzę i brud

jęk ginacych grom przekleństw $i$ harkot

trupich dzieci wzdęty śpiewa brzuch

śpiewa miasta nażarte i puste

zgietk i pośpiech zdeptany chleb

sen więzienny błyszczenie luster

brak mu tchu lecz śpiewa jeszcze

a pieśn jego rozdarty krzyk

hymn skrzywdzonych litania nieszczęść

[...] 
sucha staje na brzegu stopa

jasna panna a twarz jej przeciez

tak znajoma żobiona $w$ drewnie

[...]

tyżeś mamo - ja synku śpij

nie odejdziesz prawda-nie synku

ja zostane odejdziesz ty

musisz iść zanieść im żywej

choćby krople garsteczkę wody

złoty promyk chociażby tyle

wraca niedźwiedź unosi dzban

gdzie przechodzi tam poruszenie

a gdzie przejdzie zostaje ptomień

(Bąk 70-72)

Obszerny utwór Romana Bąka mógłby prawdopodobnie stać się wdzięcznym obiektem badań komparatystycznych, bo w swej powierzchniowej warstwie zdaje się streszczać dzieje obrazu niedźwiedzia w kulturach świata. Tytułowy motyw, będący osią kompozycyjną dyptyku, w poszczególnych częściach zostaje przecież wyposażony w dwa osobne kręgi semantyczne, odnoszące się do zasadniczych etapów kulturowej historii wspomnianego zwierzęcia. Jak przekonuje Michel Pasteureau, od trzynastego wieku wizerunek groźnego króla zwierząt był stopniowo zastępowany stereotypem niezgrabnego, ociężałego smakosza miodu, by przerodzić się następnie w budzący już tylko śmiech portret jarmarcznego tancerza, a u progu nowoczesności wcielić się ostatecznie w miłą maskotkę. Poznański poeta, z wykształcenia etnograf, skonstruował swój wiersz umiejętnie korzystając z napięcia pomiędzy biegunowo różnymi kręgami konotacji, jakie otaczają postać niedźwiedzia w naszym obszarze kulturowym. Druga część poematu, ballada cała utkana jest ze słów konotujących dzikość, grozę, potęgę, majestat i sakralność - jakby autor chciał nam przypomnieć najwcześniejszy kulturowy obraz króla puszczy ${ }^{6}$. Czytamy w niej o ogromnym, nieoswojonym zwierzęciu, zrywającym krępujące go więzy i uchodzącym w dzikie ostępy. Z pierwszej dowiadujemy się natomiast o czymś zupełnie innym. Inny jest w niej rytm, inne obrazowanie. Zastosowane przez poetę paralelizmy leksykalne i składniowe wprowadzają nas w klimat piosenki i tańca. Wszystko jest tu ludyczne - widowisko, obserwujący je tłum, jego mentalność, jego sposób wypowiadania

\footnotetext{
${ }^{5}$ Obszernie pisze o tym Pasteureau. Por. zwłaszcza ostatni rozdział La revanche de l'ours, ss. 324 401.

${ }^{6}$ Ewolucję kulturowego obrazu niedźwiedzia omawia również Bożena Kaczmarczyk-Gwóźdź, nie odwołując się do książki Pasteureau. Por. Kaczmarczyk-Gwóźdź.
} 
się oraz reagowania na bodźce. Nic dziwnego, że zamiast niedźwiedzia w centrum spektaklu pojawia się miś - jarmarczny, cyrkowy i pluszowy zarazem, bo autor nakłada na siebie wymienione pola semantyczne i sprawnie gra nimi, kreując sugestywny obraz zabawy.

Z woli autora biały niedźwiedź staje się jednak czymś innym niż poetycka narracja o ewolucji kulturowych wyobrażeń. Poeta świadomie odwraca zresztą porządek przemiany. $\mathrm{W}$ dyptyku miś zamienia się $\mathrm{w}$ niedźwiedzia, a nie niedźwiedź w misia. Dzieje się tak dlatego, że warstwa znaczeń dosłownych nie jest w utworze Bąka ani jedyną, ani najważniejszą. Opatrując dyptyk paratekstem, poeta buduje zupełnie nowe piętro znaczeń - niedosłownych, metaforycznych. Od początku czytamy wiersz mając świadomość, że w jego semantycznym centrum znajduje się postać Ojca Świętego. Motto podpowiada, że centralny dla utworu motyw zwierzęcia trzeba potraktować jako personifikację, a w sugestywnych obrazach - czy to zabawy, czy dzikich ostępów - należy szukać aluzyjnych odniesień do posługi Jana Pawła II 7 . Świat przedstawiony w utworze zbudowany jest z symboli. Domaga się nie tyle realistycznej rekonstrukcji, ile hermeneutycznej egzegezy.

Spróbujmy zatem najpierw zastanowić się nad sytuacją przedstawioną w części zatytułowanej głosy. Liczba mnoga tytułowego rzeczownika, a potem charakterystyczna forma dzierżawczego zaimka „nasz” w pierwszym wersie ewokują obraz zbiorowości, którą - jak to już zostało powiedziane - stosunkowo szybko identyfikujemy jako grupę uczestników ludycznego widowiska. Tym, co ich zgromadziło, wydaje się potrzeba rozrywki oraz możliwość dysponowania pewnym zasobem wolnego czasu, a także - co wcale nie jest bez znaczenia - pewną ilością talarów ${ }^{10}$. Spektakl nie jest bowiem dobrem oferowanym bezinteresownie. Stworzono go z myślą o sprzedaży. Nie zapomniano przy tym prawdopodobnie o zasadzie generowania jak największego zysku, bowiem treść pokazu wydaje się przystosowana do odbiorcy masowego, niezbyt niewymagającego. Jeśli możemy nadal mówić o sytuacji przedstawionej w liryku, to powiedzmy, że mamy w nim do czynienia z sytuacją charakterystyczną dla popkultury. To ona przecież - jak piszą jej znawcy - jest kulturą czasu wolnego, to ona ,jest zdecydowanie okocentryczna, potrzebuje atrakcyjnych wizualizacji” (Witek 114), to jej cechami są widowiskowość, komercja-

\footnotetext{
${ }^{7}$ Wiersz Romana Bąka powstał w 1986 roku. W obszernej korespondencji z piszącym te słowa, autor zwrócił uwagę na zasadnicze znaczenie motta w wyznaczaniu ścieżki interpretacyjnej wiersza, podkreślił także, iż kontekst jego publicystyki religijnej z tamtych lat - bardzo ważny dla odczytania utworu - nie pozwala odnieść bohatera wiersza do postaci innej niż Jan Paweł II.

${ }^{10}$ Wydaje się, że ów archaizm jest w tekście znakiem ironii i dystansu podmiotu mówiącego do przedstawianego świata.
} 
lizacja, ludyczność i symplifikacja przekazu ${ }^{11}$. Ona też zaspokaja społeczną tęsknotę za bohaterem, odznaczającym się niezwykłymi cechami ${ }^{12}$, jednocześnie powlekając wizerunek herosa papką treści dostępnych dla wszystkich i dla każdego (Krzan 76).

Jak zauważa Piotr Kowalski, „to właśnie kultura masowa wytwarza charakterystyczny mechanizm familiaryzacji w odniesieniu do zjawisk i przeżyć dla uczestników kultury masowej niewygodnych, wymykających się symplifikacjom" (Kowalski 109). W spektaklu, jaki obserwują bohaterowie utworu Bąka, niezwykłość zwierzęcia jest właśnie niezwykłością „na smyczy” - całkowicie oswojoną, w pełni kontrolowaną. Powinna budzić pewien specyficzny rodzaj zachwytu - niezbyt wyrafinowanego i powierzchownego ${ }^{13}$. Czyż nie taki wybrzmiewa w dystychu: „piękny jest nasz miś nasz biały miś / piękny i taki grzeczny i ładny"? Czy symbolem familiaryzacji obrazu świata nie są ostatnie wersy pierwszej strofy, w których śnieg spadający z hukiem zmienia się w „puch zbity w kulkę”? Jak pisze Dorota Plucińska:

Społeczna potrzeba wzoru, kreowanego przez kulturę popularną [...] zdeterminowała szereg różnorodnych działań kulturowych, których wynikiem stało się wykreowanie mitu człowieka wyjątkowego, a realnego [...] Taki bohater, kreowany w dużej mierze na wzór medialnych ikon popkultury, symbolizujący realne sacrum, pozwala wierzyć w możliwość przemiany profanum w świętość. (Plucińska 229)

Roman Bąk zdaje się nie podzielać jednak podobnego optymizmu. Przesłanie głosów wydaje się bliższe tym obserwatorom pontyfikatu Jana Pawła II, których niepokoił fakt, że Papież, korzystając z popkulturowych mediów, „sam w jakimś sensie został przez nie wchłonięty" (Gabiś). Wiersz poznańskiego autora mówi właśnie o tym - o tym, jak popkultura oswaja i zawłaszcza obraz głowy Kościoła, wyposażając bohatera wyłącznie w takie cechy, które są użyteczne w medialnym show. W ramach ludycznego pokazu dokonuje się przecież nie tylko familiaryzacja herosa, ale także infantylizacja - zarówno zresztą bohatera, jak i wszystkich uczestników widowiska. Cytowane pierwsze wersy utworu są aż nadto wymownym świadectwem zdziecinnienia umysłów - osobliwej puerylizacji wyobraźni, gustów, sposobów wyrażania emocji i ocen estetycznych. Zdaniem poety pewien rodzaj percepcji świata nie jest w stanie wytworzyć w naszej wyobraźni innego obrazu Ojca Świętego niż skrajnie infantylny. Papież miłujący jawi się jej wyłącznie jako miły czy nawet milutki. Poznański pisarz i publicysta religijny zgodziłby się

${ }^{11}$ Analizie cech popkultury poświęcono setki, jeśli nie tysiące opracowań. Wśród podstawowych, dostępnych w języku polskim warto wymienić m.in. następujące: Kłoskowska, Godzic, Krajewski.

${ }^{12}$ Pisze o tym m.in. Krajewski 233. Por. także Kowalski. Analizie postaci bohatera poświęcony jest rozdział Potoczna religijność, kicz i sakrobiznes, ss. 101-144.

${ }^{13}$ Szerzej o problemie infantylizacji sacrum pisze Jarecka. 
prawdopodobnie z niektórymi spostrzeżeniami, zawartymi w cytowanym artykule Krzysztofa Mazura (19).

Czy jednak w analizowanym wierszu przedmiotem analizy poety jest wyłącznie popkulturowy przekaz i to, jaki obraz Papieża jest on w stanie osadzić w naszej świadomości? Gdyby tak było, tekst musiałby się kończyć na pierwszej strofie, bo kolejne nie są już piosenką egzaltowanego thumu, lecz wypowiedzią narratora mocno zdystansowanego wobec zjawiska, jakie przyszło mu charakteryzować. Nie tylko kursywa jest w kolejnych strofach znakiem ironii, lecz także swoista hiperbolizacja rozmaitych cech mentalności spektatorów, a wreszcie i wszechogarniająca groteska bynajmniej niezacierająca różnicy między tym, co wysokie i tym, co niskie, tym, co śmieszne i tym, co straszne, lecz twórczo wyzyskująca ich radykalną antynomiczność. Właśnie grotesce Roman Bąk powierza bowiem najważniejszą dla przesłania utworu funkcję ukazania zasadniczej różnicy pomiędzy osobą i tym, jak ją postrzegamy; pomiędzy człowiekiem i jego wizerunkiem, pomiędzy tym, kim Papież jest i tym, kim jest on dla nas. Artysta stopniowo wzmacnia groteskowe napięcie nie tylko po to, by przydać medialnemu widowisku cech karykaturalnych, lecz także, a nawet przede wszystkim po to, by pokazać, że osoba Ojca Świętego w przedziwny sposób wymyka się medialnemu formatowi, nie mieści się w ramach powszechnie przyjmowanego wizerunku. Począwszy od drugiej strofy podmiot mówiący dba zatem o to, by pokazać, że miś niezupełnie poddaje się cyrkowym konwencjom. Zrazu wspiera się o niebo, potem nie chce przestać grać, a jeśli już tańczy, to na pewno poza przestrzenią show - ,po śmietniskach szynach szkłach”. Czytamy, że ,potyka się fałszuje”, a wreszcie „unosi się i lata” - całkowicie na przekór oczekiwaniom, a więc i wbrew percepcyjnym możliwościom tłumu. Już w glosach jesteśmy w stanie dostrzec, że Papież jest kimś więcej, niż przewidują konwencje popkulturowego spektaklu. W pełni format osoby Papieża odsłania się jednak dopiero w drugim skrzydle dyptyku, w którym poeta korzysta z romantycznego kodu kulturowego.

Ballada stanowi bowiem swoisty dalszy ciąg głosów. Zaczyna się od obrazu zwierzęcia na smyczy, który poznaliśmy już wcześniej, tyle że narrator mówi teraz o uwolnieniu się niedźwiedzia z więzów. Widzimy też, że odzyskana wolność została przedstawiona w tym fragmencie utworu nie tylko jako „wolność od”, ale także, a nawet przede wszystkim, jako „wolność do”. Zwierzę zrywa pęta nie tylko dlatego, że nie może już dłużej grać roli jarmarcznego bohatera, ale również po to, by znaleźć się w takim środowisku, które jest jego środowiskiem rodzimym i naturalnym. Miś z głosów, całkowicie oswojony i podporządkowany prawom show, w drugiej części dyptyku „idzie na zew” - odzyskuje swoją prawdziwą, niedającą się oswoić naturę króla górskiej przyrody, a więc również swoją godność. W jakimś sensie schodzi do jej źródła i pije z niego. Warto w każdym razie pamiętać, że przestrzeń wykreowana w balladzie - niezwykle sugestywna, tajemnicza, na swój sposób romantyczna - ugi- 
na się jednocześnie od znaczeń symbolicznych. Noc nie jest w tym wierszu zwykłą nocą, woda nie jest zwykłą wodą. Także droga, jaką przebywa bohater, nie wydaje się zwyczajną górską wędrówką.

Zastanawia bowiem fakt, że bohater idzie zupełnie samotnie i że podąża ścieżką, „której nikt nie zna”. Nie wiemy przecież, czy chodzi o szlak, którego nie zna nikt inny niż on, czy też o taki, którego nie zna żadne spośród ziemskich stworzeń. Podobnie chcielibyśmy zapytać o głos - czy także on nie pochodzi z jakiejś innej rzeczywistości - niedostępnej ziemianom. Bo dzikość ostępów, przez które brnie bohater, ich balladowa niesamowitość ma w sobie coś niemal nadprzyrodzonego, wydaje się osnuta aurą mrocznego tremendum. Czy jest zatem przedprożem sacrum? Wydaje się, że tak. Noc, w którą zagłębia się protagonista, ma przecież w sobie coś z nocy mistyków - odnosi się do przeżyć wewnętrznych, do duchowego cierpienia, którego finałem staje się zdolność do głębokiego zjednoczenia „ja” z nadprzyrodzonym „Ty”. „Ścieżka, której nikt nie zna” prowadzi bohatera utworu w samo centrum doświadczenia religijnego.

Jeśli opisana scena przy zdroju staje się w liryku symbolicznym obrazem relacji religijnej czy wręcz doświadczenia mistycznego, to warto również podkreślić, że poeta dokłada starań, by nie pozbawić tego przeżycia wymiarów dramatycznych. Przeciwnie: chce wydobyć je i oświetlić w sposób możliwie najbardziej jaskrawy. Przestrzeń otaczająca bohatera, jest przestrzenią zupełnie obcą - ciemną, kamienną i chłodną. Poruszanie się w niej zmusza do niemałego trudu - psychicznego i fizycznego; wymaga zmęczenia i bólu. Głęboka relacja z Bogiem - zdaje się przekonywać pisarz - nie jest możliwa bez uprzedniej wytężonej pracy wewnętrznej, bez poświęcenia i przezwyciężania własnych ograniczeń - choćby tych związanych z cielesnością. Poeta podkreśla przy tym, że ciemność wewnętrznego wysiłku nie jest pozbawiona światła nadziei i że to właśnie ono rozbłyskuje ostatecznie w upragnionym spotkaniu człowieka i Boga. Co wiemy o wymiarach i przestrzeni tego spotkania? Najpierw chyba to, że poeta - nawiązując do języka mistyki - mówi o niej za pomocą symboliki akwatycznej. Toń jest jasna, odzywa się w niej dzwon, a w jej głębi, tak jak w głębi kościoła - świeci światło. Górski zdrój nabiera cech eklezjalnych - wrażenie to wzmacniają litanijne apostrofy, wypełniające tercynę, zaczynającą się od słów: „wodo żywa, krynico blasku/ krypto ciszy, płomieniu łaski”. Cała ta strofa wypełniona jest po brzegi chrystologiczną symboliką - jakby była początkiem liturgicznej doksologii. Zaczynamy się domyślać, że gest bohatera ma wymiar sakramentu. Ten, kto pije wodę opisaną w wierszu, pije samego Boga.

Wypada więc podkreślić również, że poeta dba o to, by nie zamazywać dialogicznego charakteru bosko-ludzkich relacji. Wpatrując się w sytuację przedstawioną w wierszu, zauważamy, że Bycie-z-Bogiem nie odbiera mowy. Przeciwnie: ono ją warunkuje. Nadprzyrodzone „Ty”, które ofiarowuje siebie bohaterowi, domaga 
się odpowiedzi, stymuluje jego głos. Czym jest zatem przejmująca pieśń, jaka została opisana w balladzie? To, co śpiewa protagonista utworu, wydaje się ludzką egzystencją. Jest losem. Pojedynczym i zbiorowym. Jest historią. Mieści w sobie kłamstwo i pustkę, nędzę i sytość, pośpiech i zbrodnię, litanię nieszczęść i ból. Jest skargą. Jak daleko stąd do obrazu medialnego idola! Papież z drugiej części dyptyku to Papież-prorok. To ktoś, kto staje się reprezentantem całej ludzkości po to, by przedstawić pieśń jej dramatycznego istnienia samemu Bogu. To ktoś, kto staje się reprezentantem Boga, by przedstawić ludzkości Boże słowo.

$\mathrm{Z}$ niezwykłym taktem i subtelnością poeta zarysowuje napięcie związane z zarysowaną wyżej rolą. Wpisuje je w liryczną scenę spotkania syna z matką. Znamienne dla pontyfikatu Jana Pawła II hasło totus tuus pod piórem artysty zmienia się w poruszającą rozmowę głowy Kościoła z Królową Niebios - wszak to jej twarz rozpoznajemy w portrecie ,jasnej panny” o dobrze znanych rysach. Brud sierści, która wymaga obmycia, niepokój serca, stają się teraz symbolem tego wszystkiego, co mocarz dźwiga na swych barkach - całej dojmującej, bolesnej wiedzy o nieszczęściach świata. Matczyne pocieszenie nie jest jednak wyłącznie współczuciem. Scenę kończy rytuał powierzenia ważnego zadania. „Musisz iść zanieść im żywej / choćby kroplę garsteczkę wody" - mówi matka. Syn otrzymuje od niej misję kapłana-proroka, który będzie niósł ludziom Boga. Jego posługę poeta otacza symbolami działania Ducha Świętego: ,gdzie przechodzi tam poruszenie / a gdzie przejdzie zostaje płomień”. Papieska posługa przekracza ramy świata dostępnego zmysłami - zdaje się mówić autor. Do jej istoty należy relacja z Bogiem. Miarą jej skuteczności nie jest popularność, lecz świętość.

Starając się uporządkować ogromny i zróżnicowany obszar lirycznych portretów Jana Pawła II, próbowałem kiedyś pisać o ich spektrum gatunkowym - rozciągającym się od wierszy-reportaży po modlitwy poetyckie. Pamiętając o licznych antologiach i wstępach do nich, wspominałem także o kilku podstawowych konwencjach dostarczających lirycznych ram wizerunku, już to religijnego przywódcy, już to rodaka, już to przyjaciela i duchowego mistrza (Kudyba, „Postać Jana Pawła II”). Nie udało mi się jednak dotrzeć wówczas do omówionych wyżej utworów Romana Bąka i Tadeusza Dąbrowskiego, odsłaniających portret „papieża medialnego”. Obydwa liryki nie doczekały się dotąd ani jednej analizy, choć przecież na nie zasługują. Zdaję sobie sprawę, że oba omówione wyżej teksty wymagały uruchomienia kontekstów i skorzystania z inspiracji metodologicznych, które wobec wierszy o Janie Pawle II nie były dotąd przywoływane. Nie tracę przecież nadziei, że ich aplikacja przyniosła ciekawe rezultaty poznawcze i poszerzyła w sposób twórczy obszar naszej wiedzy o tym, w jaki sposób współcześni poeci polscy starali się zapisać swe doświadczenie spotkania z Ojcem Świętym. 


\section{BIBLIOGRAFIA}

Babuchowski, Szymon. „Milion obrazów papieża”. Gość Niedzielny, nr 41, 2008, ss. 67-67.

Ballardini, Bruno. Jezus i biel stanie się jeszcze bielsza. Jak Kościót wymyślił marketing. Tłum. Michał Oleksiak, WAB, 2008.

Bąk, Roman. Którzy by mogli powiedzieć. Inicjatywa Wydawnicza T.F.C., 1991.

Dąbrowski, Tadeusz. „***[Papieżowi ślina kapie]”. Studium, 2-3, 2004, ss. 30-30.

Godzic, Wiesław. Oglądanie i inne przyjemności kultury popularnej. Universitas, 1996.

Ikonowicz, Mirosław. „Papież medialny”. Przeglad Tygodniowy, 21, 1997, ss. 12-13.

Jarecka, Urszula. „Świeckie «Anioły». Wyobrażenia para-anielskie w kulturze popularnej”. Religijność w dobie popkultury, red. Tomasz Chachulski, Jerzy Snopek, Magdalena Ślusarska, Wydawnictwo UKSW, 2014, ss. 146-172.

Kłoskowska, Alina. Kultura masowa. PWN, 2005.

Kosmanowa, Bogumiła. Media dawne i wspótczesne. Wydawnictwo UAM, 2008.

Kowalski, Piotr. Popkultura i humaniści. Daleki od kompletności remanent spraw, pogladów mistyfikacji. Wydawnictwo UJ, 2004.

Krajewski, Marek. Kultury kultury popularnej. Wydawnictwo UAM, 2003.

Krzan, Katarzyna. Ekstaza w wersji pop. Poszukiwania mistyczne w kulturze popularnej. WAiP, 2000.

Kudyba, Wojciech. „Lekkość, uwieranie”. Twórczość, nr 11, 2006, ss. 134.

Kudyba, Wojciech. „Postać Jana Pawła II we współczesnej poezji polskiej”. Promieniowanie świętości. Jan Pawet II a literatura, red. Krzysztof Dybciak, Civitas Christiana, 2011, ss.111-120.

Mazur, Krzysztof. „Tak, zabiliśmy Proroka. Jak odrzuciliśmy nauczanie Jan Pawła II”. Pressje, 2011, ss. $18-27$.

Morawiec, Arkadiusz. „Ślicznotka Hauptsturmführera Mengelego. O krytycznej powieści Zyty Rudzkiej”. Er(r)go, nr 14, 2007, ss. 87-99.

Pasteureau, Michel. L'Ours. Histoire d'un roi déchu. Seuil, 2007.

Plucińska, Dorota. „Hagiografia we współczesnej kulturze popularnej: Jan Paweł II w konwencji humorystyczno-anegdotycznej". Religijność w dobie popkultury, red. Tomasz Chachulski, Jerzy Snopek, Magdalena Ślusarska, Wydawnictwo UKSW, 2014, ss. 211-229,

Politi, Marco. Papa Wojtyła. Pożegnanie. Tłum. Jarosław Mikołajewski. Wydawnictwo Literackie, 2008.

Rabizo-Birek, Małgorzata. „Wyobraźnia religijna w najnowszej poezji polskiej”. Tygiel Kultury, nr 1/3, 2006, ss. 82-92.

Sinkowski, Adrian. „Literatura która przywraca wzrok”. Idziemy, nr 36, 2009, ss. 42-42.

Skórczewski, Dariusz. „Hegemon jako idol. Zachód jako hegemon wyobrażony”. Idol w kulturze, red. Edward Fiała i in., Wydawnictwo KUL, 2017, ss. 93-127.

Śliwiński, Piotr. „Asystent Boga?”. Tygodnik Powszechny, nr 40, 2009, ss. 48-48.

Witek, Halina. „Konsument sacrum. Wokół kaplicy św. Barbary w Silesia City Center”. Religijność w dobie popkultury, red. Tomasz Chachulski, Jerzy Snopek, Magdalena Ślusarska, Wydawnictwo UKSW, 2014, ss. 106-115.

Wołpiuk, Kazimierz. „Jan Paweł II - papież komunikacji i historycznego przełomu”. Studia Teologiczne, $\mathrm{nr} 27,2009$, ss. 169-186.

\section{NETOGRAFIA}

Gabiś, Tadeusz. „Jan Paweł II, czyli o papiestwie w dobie masowych mediów”, www.tomaszgabis. pl/2020/01/03/jan-pawel-ii-czyli-o-papiestwie-w-dobie-masowych-mediow/. Dostęp 15.04.2020.

Kaczmarczyk-Gwóźdź, Bożena. „Od niedźwiedzia do misia zabawki: w stronę gadżetu popkultury”, journals.indexcopernicus.com/api/file/viewByFileId/459544.pdf. Dostęp 17.04.2020. 


\section{MEDIALNY, ŚWIĘTY. \\ JAN PAWEŁ II W POEZJI WSPÓŁCZESNEJ}

Streszczenie

Jan Paweł II to nie tylko pisarz, ale także niezwykle popularny bohater współczesnych utworów literackich. Niektórzy poeci ciekawie problematyzują zagadnienie obecności postaci tego Papieża w mediach. Wiersz Tadeusza Dąbrowskiego przenosi naszą uwagę z pojedynczego telewizyjnego kadru w obszar refleksji nad rolą mediów w naszym cyfrowym świecie. Natomiast liryk Romana Bąka zawiera najpierw karykaturalny obraz medialnego show, by w drugiej części dyptyku ukazać Papieża-proroka i mistyka.

Słowa kluczowe: Jan Paweł II; poezja; media; Roman Bąk; Tadeusz Dąbrowski

\section{A SAINT IN THE MEDIA. \\ JOHN PAUL II IN CONTEMPORARY POETRY}

\section{Sum mary}

John Paul II is not only a writer, but also an extremely popular hero of contemporary literary works. Some poets interestingly problematise the issue of the presence of the Pope's figure in the media. Tadeusz Dąbrowski's poem transfers our attention from a single television frame to a reflection on the role of the media in our digital world. In contrast, the lyrics of Roman Bąk first contain a caricatured image of the media and show the Pope-prophet and mystic in the second part of his diptych.

Keywords: John Paul II; poetry; media; Roman Bąk; Tadeusz Dąbrowski 